\title{
Efficiency of turbidity and BOD removal from secondarily treated sewage by electrochemical treatment
}

\section{A. K. Chopra and Arun K umar Sharma*}

Department of Zoology and Environmental Sciences Gurukula Kangri University, Haridwar-249404 (Uttarakhand), INDIA *Corresponding author. E-mail: asharma.env@gmail.com

Received: September 12,2012; Revised received: 0 ctober 15, 2012; Accepted: November 20, 2012

Abstract: The present investigation observed the effect of operating time, current density, $\mathrm{pH}$ and supporting electrolyte on the removal efficiency of Turbidity (TD) and Biochemical oxygen demand (BOD) of secondarily treated sewage (STS) using electrochemical process. A glass chamber of 2 litre volume was used for the experiment with two electrode plates of aluminum, each having an area of $125 \mathrm{~cm}^{2}$ and $2 \mathrm{~cm}$ distance apart from each other. The treatment showed that the removal efficiency of TD and BOD increased to 87.41 and $81.38 \%$ respectively with the increase of current density $\left(1.82-7.52 \mathrm{~mA} / \mathrm{cm}^{2}\right)$, time $(5-40$ mins.) and different $\mathrm{pH}(4-8)$ of the STS. The most effective removal efficiency was observed around the $\mathrm{pH}$ 7. Further, $0.5 \mathrm{~g} / \mathrm{l} \mathrm{NaCl}$ as a supporting electrolyte for electrochemical treatment of STS was found to be more efficient for an increase to $95.56 \%$ and $86.99 \%$ for the removal of TD and BOD at $7.52 \mathrm{~mA} / \mathrm{cm}^{2}$ current density in 40 mins. respectively. The electrode and energy consumption was found to vary from $2.52 \times 10^{-2}$ to $10.51 \times 10^{-2} \mathrm{~kg} \mathrm{Al} / \mathrm{m}^{3}$ and $2.76 \mathrm{kwh} / \mathrm{m}^{3}$ to $45.12 \mathrm{kWh} / \mathrm{m}^{3}$ depending on the operating conditions. The kinetic study results revealed that reaction rate $(\mathrm{k})$ increased from 0.0174 to $0.03 \mathrm{~min}^{-1}$ for TD and 0.0169 to $0.024 \mathrm{~min}^{-1}$ for BOD with increase in current density from 1.82 to $7.52 \mathrm{~mA} / \mathrm{cm}^{2}$.

Keywords: Aluminium electrode, BOD, Current density, Electrochemical treatment, Supporting electrolyte

\section{INTRODUCTION}

Sewage is defined as domestic wastewater excluding water from the toilet, and generally includes wastewater from baths, showers, hand basins, washing machines, dishwashers and kitchen sinks. Sewage wastewater contains number of hazardous organic, inorganic and microbiological impurities. The discharge of raw or improper treated sewage wastewater into the water body and environment is one of the main sources of pollution (Gijzen, 2002). Interest in wastewater recycling has been raised by the increase of water demand, water shortage due to low rainfall, economic and environmental issues (Eriksson et al., 2002). There are two main objectives of wastewater treatment, one is to protect the environment and the other one is to conserve fresh water resources (Bukhari, 2008).

Conventional treatment methods often induce a chemical reaction through the use of coagulants, flocculants and other additives that aid in the removal or sedimentation of inorganic and organic contaminants present in wastewater. There is an urgent need for the development of a more sustainable treatment process. Electrochemical seems to be a promising treatment method due to its high effectiveness, its lower maintenance cost, less need for labor and rapid achievement of results (Feng et al., 2003). The key process in electrolysis is the interchange of atoms and ions by the removal or addition of electrons from an external circuit. The anode is involved in rapid adsorption of soluble organic compounds and trapping of colloidal particles that can be easily separated from an aqueous medium by $\mathrm{H}_{2}$ flotation. When an electrical current is applied, the positive ions move to the cathode, while the negative ions move to the anode (Cho et al., 2010 and Chopra et al., 2011). This electrolytic process of generating metallic hydroxide flocks in situ via electrodissolution of the sacrificial anode immersed in the wastewater is referred to as electrocoagulation (EC). The generation rate of flocks can be controlled by applying the current. The electrochemically generated metallic ions can be hydrolyzed next to the anode and generate a series of metal hydroxides that are able to destabilize the dispersed particles present in the wastewater to be treated. The destabilized particles are believed to be responsible for the aggregation and precipitation of the suspended particles and for the adsorption of the dissolved and/or colloidal pollutants which are subsequently removed by sedimentation and flotation (Bayramoglu et al., 2004; Lung Chou, 2010).

Electrolytic mechanism with Al electrodes: The electrolytic process involves the generation of coagulants in situ by electrolytic oxidation of the sacrificial electrode material. Aluminum/ iron are usually used as electrodes and their cations are generated by dissolution of sacrificial anodes upon the application of a direct current. The metal ions generated are hydrolyzed in the electrochemical cell 
to produce metal hydroxide ions according to reactions (1) to (3) and the solubility of the metal hydroxide complexes formed depends on $\mathrm{pH}$ and ionic strength. Insoluble flocs are generated at $\mathrm{pH}$ range between 6.0 and 7.0 as can be seen from the solubility diagram of aluminum hydroxide $\mathrm{Al}(\mathrm{OH})_{3}$ showing $\mathrm{pH}$ versus solubility (Bensadok et al., 2008). The Al plates are also finding applications in wastewater treatment either alone or in combination with $\mathrm{Fe}$ plates due to the high coagulation efficiency of $\mathrm{Al}_{3}{ }^{+} \mathrm{Chen}$ (2004). Mollah et al., (2001) has reported that the electrolytic dissolution of the $\mathrm{Al}$ anode produces the cationic monomeric species such as $\mathrm{Al}_{3}^{+}$and $\mathrm{Al}(\mathrm{OH})_{2}{ }^{+}$under acidic conditions. At appropriate $\mathrm{pH}$ values, they are transformed initially into $\mathrm{Al}(\mathrm{OH})_{3}$ and finally polymerized to $\mathrm{Al}_{\mathrm{n}}(\mathrm{OH})_{3 \mathrm{n}}$ according to the following reactions:

$\mathrm{Al} \rightarrow \mathrm{Al}_{(\mathrm{aq})}^{3+}+3 \mathrm{e}^{-}$

$\mathrm{Al}_{(\text {aq) }}{ }^{3+}+3 \mathrm{H}_{2} \mathrm{O} \rightarrow \quad \mathrm{Al}(\mathrm{OH})_{3}+3 \mathrm{H}_{(\text {(aq) }}^{+}$

$\mathrm{nAl}(\mathrm{OH})_{3} \rightarrow \mathrm{Al}_{\mathrm{n}}(\mathrm{OH})_{3 \mathrm{n}}$

However, depending on the $\mathrm{pH}$ of the aqueous medium other ionic species, such as $\mathrm{Al}(\mathrm{OH})_{2}{ }^{+}, \mathrm{Al}_{2}(\mathrm{OH})_{2}{ }^{4+}$ and $\mathrm{Al}(\mathrm{OH})_{4}^{-}$may also be present in the system. In addition, various forms of charged multimeric hydroxo $\mathrm{Al}^{3+}$ species may be formed under appropriate conditions. These gelatinous charged hydroxo cationic complexes can effectively remove pollutants by adsorption. (Yetilmezsoy et al., 2009).

The present study was focused on the electrolytic treatment of secondarily treated sewage (STS) and to find out the treatability of STS by electrolytic treatment at various operating conditions using $\mathrm{Al}$ electrodes and also with the addition of $\mathrm{NaCl}$ as a supporting electrolyte for the removal of TD and BOD.

\section{MATERIALS AND METHODS}

Collection of STS samples: The samples of STS were collected from the outlet of activated sludge process (ASP) of the sewage treatment plant (STP), Jagjeetpur, Haridwar (Uttarakhand), India and brought to the laboratory and then used for electrolytic treatment using $\mathrm{Al}-\mathrm{Al}$ electrode combination. The $\mathrm{pH}$ of STS was adjusted before the electrochemical process and was maintained by adding the required amount of $\mathrm{H}_{2} \mathrm{SO}_{4}(1 \mathrm{M})$ or $\mathrm{NaOH}$ (1 M). The characteristics of STS are shown in Table 1. Electrolytic experimental set up: The schematic arrangement of the experimental setup is shown in Fig. 1. The experiments were carried out in a rectangular vessel having capacity of $2 \mathrm{~L} \mathrm{STS}$. The $\mathrm{Al}$-Al electrode plates each having surface area of $125 \mathrm{~cm}^{2}$ were connected to their respective anode and cathode leading to the D.C. power supply (LMC electronics, India 0 -500 V and 0- 2 A) and energized for a required duration of time at different voltages and currents. The inter electrode distance $(2.5 \mathrm{~cm})$ between the two neighboring electrode plates was fixed. All the experiments were performed at room temperature $\left(30 \pm 2^{\circ} \mathrm{C}\right)$ and at a constant stirring speed $(100 \mathrm{rpm})$ to maintain the uniform mixing of STS during the electrolytic treatment. Before conducting an experiment, the electrodes were washed with water, dipped in dilute hydrochloric acid $(\mathrm{HCl})(5 \% \mathrm{v} / \mathrm{v})$ for 5 mins., thoroughly washed with water and then finally rinsed twice with distilled water. Different doses of $\mathrm{NaCl}$ $(0.1,0.3$ and $0.5 \mathrm{~g} / \mathrm{l})$ were added to the electrochemical process as a supporting electrolyte to observe TD and BOD removal efficiency. After electrolytic treatment, the STS was allowed to stand for two hours and then sampled for TD and BOD analysis of the STS.

A nalytical methods: The TD, BOD and pH of STS were analyzed before and after the electrolytic treatment following the standard methods (APHA, 2005). The calculation of TD and BOD removal efficiency after electrolytic treatment was carried out using the formula.

$$
\mathrm{CR} \%=\stackrel{\mathrm{Co}-\mathrm{C}}{\underset{\mathrm{Co}}{\rightleftharpoons}} \times 100
$$

Where $\mathrm{C}_{0}$ and $\mathrm{C}$ are concentrations of wastewater before and after electrolysis.

\section{RESULTS AND DISCUSSION}

Effect of current density: It has been established that the current density is an important operating factor influencing the performance of electrochemical process which determines the coagulant dosage (Tezcan et al., 2006). This is ascribed to the fact that at high current density, the extent of anodic dissolution of aluminum increases, resulting in a greater amount of precipitate for the removal of pollutants. Moreover, bubble generation rate increases and the bubble size decreases with increasing current density. These effects are both beneficial for high pollutant removal by $\mathrm{H}_{2}$ flotation (Kobya et al., 2006). Turbidity removal occurs as a result of destabilization of colloids due to the effect of electric field generated between the electrodes and the reactions with coagulating compounds formed in situ during anode oxidation, followed by a subsequent flotation of agglomerates of the particles (Szpyrkowicz 2002). Merzouk et al., (2009) observed that with the increase of current density from 11.55 to $91.5 \mathrm{~mA} / \mathrm{cm}^{2}$, the TD removal efficiency decreased and did not change after $10 \mathrm{~min}$ retention time of the wastewater in the EC unit. Nasrullah et al., (2009) observed that the maximum removal efficiency of BOD $(98.3 \%)$ was at the higher current density $\left(1816 \mathrm{~A} / \mathrm{m}^{2}\right)$ and reaction time (30 mins.). During present study, an increase in current density from 1.84 to $7.52 \mathrm{~mA} / \mathrm{cm}^{2}$ increased the TD and BOD removal efficiency from $66.86 \%$ to $83.21 \%$ and 60.19 to $71.29 \%$ respectively at $30 \mathrm{~min}$ electrolytic time (Fig.2). 


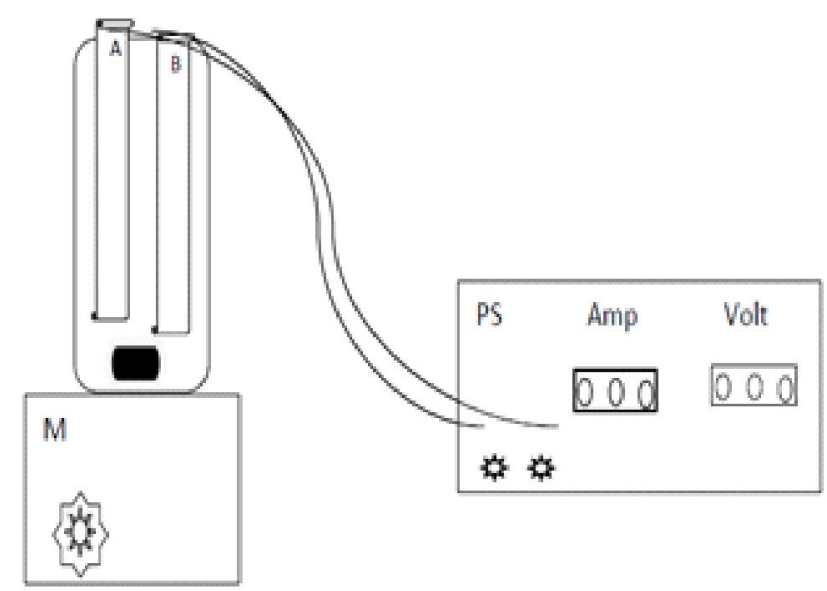

Fig.1. Systematic design of Experimental set-up. (A- Anode; BCathode; R-Reactor; M-Magnetic stirrer; PS- DC power supply; Amp-C urrent and Volt-Voltage).

The removal efficiency can be attributed to the fact that the increase in the current density increases large amount ion production on both the anode and cathode. The higher current density increased the rate of flock formation, which in turn influenced the removal efficiency of TD and BOD from of STS.

Effect of electrolysis time: It has been indicated that increase in electrolytic time or current intensity improves the efficiency of turbidity removal by faster producing hydrolyze products (Rahmani,2008). These enhancing effects are attributed to the increase in the driving force of the electrode reaction and the increase in current voltage. This is because that the potential is a major driving force for the respective phenomena of interest in electrochemical reactors (Philippe et al., 2003).

During the treatment, the anodic electrode dissolution leads to release of $\mathrm{Al}^{+3}$ ions in to the STS and $\mathrm{OH}^{-}$ions from the cathode which form the $\mathrm{Al}(\mathrm{OH})_{3}$. The TD and BOD removal efficiency depended directly on the coagulant generated from the electrodes. In the present study, it was observed that the increase in the operating time from 5 to 40 min yielded an increase in the TD and BOD from $44.08 \%$ to 87.41 and 29.61 to $81.38 \%$ respectively. As seen in Fig. 3, the removal efficiency of TD and BOD increased rapidly in the first $20 \mathrm{~min}$ of the electrolytic treatment. This is due to the increase in concentration of aluminum and their hydroxides in the STS during electrolytic treatment.

Effect of $\mathrm{pH}$ : The $\mathrm{pH}$ is an important parameter that can influence the electrolytic process. It is well known that $\mathrm{pH}$ of raw wastewater can either have a positive or negative influence on the treatment quality as it would affect the stability of various hydroxide species formed (Mollah et al.,2001). Likewise, the change in $\mathrm{pH}$ can modify the surface charge of particles and greatly influences the removal of colloidal dispersed organics from the solution (Jolivet et al., 1994). In the present study, the different
Table 1. Characteristics of STS.

\begin{tabular}{lc}
\hline Parameter & M ean \pm S.D \\
\hline $\mathrm{pH}$ & $7.54 \pm 0.19$ \\
Conductivity $(\mu \mathrm{S})$ & $766.8 \pm 18.09$ \\
TDS $(\mathrm{mg} / \mathrm{l})$ & $527.5 \pm 19.88$ \\
Turbidity $(\mathrm{NTU})$ & $17.08 \pm 3.15$ \\
BOD $(\mathrm{mg} / \mathrm{l})$ & $48.36 \pm 4.33$ \\
\hline
\end{tabular}

initial concentrations of $\mathrm{pH}$ (5-8) of STS at optimum current density $\left(5.72 \mathrm{~mA} / \mathrm{cm}^{2}\right)$ and operating time (40 mins.) indicated the removal efficiency of TD and BOD increased from $76.88 \%$ to $85.45 \%$ and 74.23 to $76.45 \%$ respectively with an increase in the $\mathrm{pH}$ from 5 to 7 . However, an increase in $\mathrm{pH}$ to more than the 7 decreased the removal efficiency of TD and BOD from 87.48 to 85.45 $\%$ and $81.33 \%$ to $76.45 \%$ respectively (Fig. 4 ).

It may be attributed that at low $\mathrm{pH}$, such as $2-3$, cationic monomeric species $\mathrm{Al}^{3+}$ and $\mathrm{Al}(\mathrm{OH})_{2}^{+}$predominate. When $\mathrm{pH}$ is between 4 and 9, the $\mathrm{Al}^{3+}$ and $\mathrm{OH}^{-}$ions generated by the electrodes react to form various monomeric species such as $\mathrm{Al}(\mathrm{OH})_{2}{ }^{+}, \mathrm{Al}(\mathrm{OH})_{2}{ }^{2+}$, and polymeric species such as $\mathrm{Al}_{6}(\mathrm{OH})_{15}{ }^{3+}, \mathrm{Al}_{7}(\mathrm{OH})_{17}{ }^{4+}, \mathrm{Al}_{3}(\mathrm{OH})_{34}{ }^{5+}$ that finally transform into insoluble amorphous $\mathrm{Al}(\mathrm{OH})_{3(\mathrm{~s})}$ through complex polymerization/precipitation kinetics (Bayramoglu et al.,2004).When pH is higher than 10, the monomeric $\mathrm{Al}(\mathrm{OH})_{4}^{-}$anion concentration increases at the expense of $\mathrm{Al}(\mathrm{OH})_{3(\mathrm{~s})}$. In addition, the cathode may be chemically attacked by $\mathrm{OH}^{-}$ions generated together with $\mathrm{H}_{2}$ at high $\mathrm{pH}$ values (Alinsafi et al., 2005):

$2 \mathrm{Al}+6 \mathrm{H}_{2} \mathrm{O}+2 \mathrm{OH}^{-} \rightarrow 2 \mathrm{Al}(\mathrm{OH})_{4}+3 \mathrm{H}_{2}$

Two main mechanisms are generally considered one is precipitation for $\mathrm{pH}$ lower than 4 and the other adsorption for higher $\mathrm{pH}$. Adsorption may proceed on $\mathrm{Al}(\mathrm{OH})_{3}$ or on the monomeric $\mathrm{Al}(\mathrm{OH})_{4}$ anion depending on the chemical structure of the pollutant.

Effect of supporting electrolyte: The increase of the conductivity by the addition of $\mathrm{NaCl}$ is known to reduce the cell voltage $\mathrm{U}$ at constant current density due to the decrease of the ohmic resistance of wastewater (Daneshvar et al.,2006, Bayramoglu etal.,2004 and, Kovya et al., 2006). Vlyssides and Israilides (1997) have indicated that when chlorides are present in the solutions, the products of anodic discharge are $\mathrm{Cl}_{2}$ and $\mathrm{OCl}^{-}$. The $\mathrm{OCl}^{-}$ itself is a strong oxidant, which is capable of oxidizing organic molecules present in wastewater. Thus, the addition of $\mathrm{NaCl}$ not only increases the conductivity but also contributes strong oxidizing agents.Lee \& Pyun ( 1999) specified that this was probably because of the $\mathrm{NaCl}, \mathrm{Cl}^{-}$anions increase that can destroy the passivation layer and increase the anodic dissolution rate of metal, either by the incorporation of $\mathrm{Cl}^{-}$into the oxide film or by the participation of $\mathrm{Cl}^{-}$in the metal dissolution reaction. The effect of supporting electrolyte on the TD and BOD 
Table 2. Rate constant $\left(\mathrm{k}\left(\mathrm{min}^{-1}\right)\right.$ values at variable current density and their correlation coefficients $\left(\mathrm{r}^{2}\right)$.

\begin{tabular}{ccccc}
\hline $\begin{array}{c}\text { Current density } \\
\left(\mathrm{mA} / \mathrm{cm}^{2}\right)\end{array}$ & $\begin{array}{c}\text { TD } \\
\mathrm{k}\left(\mathrm{min}^{-1}\right)\end{array}$ & $\mathrm{r}^{2}$ & $\begin{array}{c}\mathrm{BOD} \\
\mathrm{k}\left(\mathrm{min}^{-1}\right)\end{array}$ & $\mathrm{r}^{2}$ \\
\hline 1.84 & 0.0174 & 0.884 & 0.0169 & 0.997 \\
3.28 & 0.0205 & 0.928 & 0.0195 & 0.995 \\
6.24 & 0.0246 & 0.956 & 0.0224 & 0.996 \\
7.52 & 0.03 & 0.982 & 0.0243 & 0.998 \\
\hline
\end{tabular}

removal efficiency is shown in Fig. 5. The concentration of $\mathrm{NaCl}$ in STS increased the conductivity and current during the electrolytic treatment. The addition of $\mathrm{NaCl}$ increased the ionic strength and current at the same voltage. Three supporting electrolyte concentrations $(0.1$, 0.3 and $0.5 \mathrm{~g} / \mathrm{l} \mathrm{NaCl}$ ) used in the electrolytic treatment indicated that the efficiency of TD and BOD removal increased with increase in supporting electrolyte concentration (Fig. 5).

Further, it was indicated that the TD and BOD removal efficiency increased from 87.48 to $95.56 \%$ and 81.33 to $86.99 \%$ respectively at the optimum conditions (current density $7.52 \mathrm{~mA} / \mathrm{cm}^{2}$; operating time 40 mins. and $\mathrm{pH} 7$ ) of the electrolytic treatment (Fig. 5).

Operating cost: Electrical energy and electrode consumption are important economical parameters in EC process. In EC process the operating cost includes

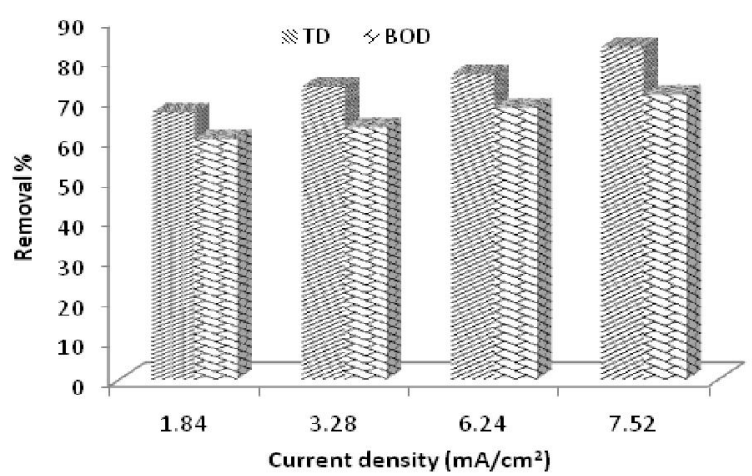

Fig. 2. Effect of current density on TD and BOD removal of STS water.

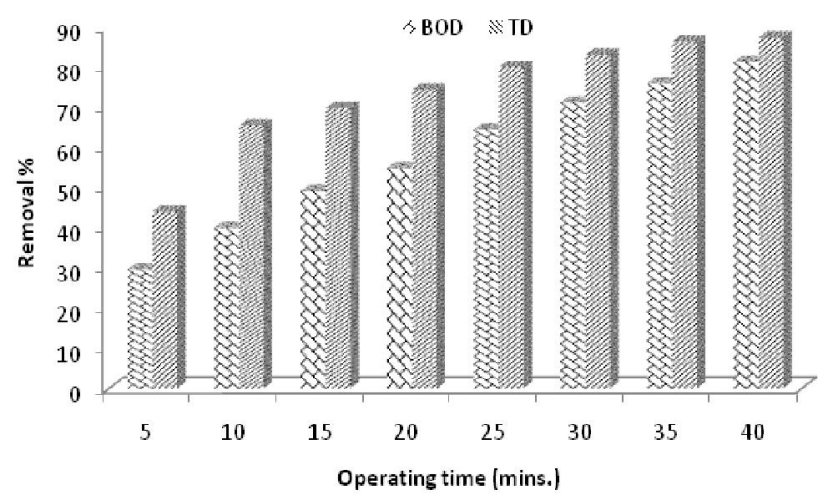

Fig. 3. Effect of operating time on TD and BOD removal of STS. material, mainly electrodes and electrical energy costs, as well as labor, maintenance, sludge dewatering and its disposal. In the present study, energy and electrode material costs have been taken into account as major cost items in the calculation of the operating cost (US \$/ $\mathrm{m}^{3}$ ) (Ghosh et al., 2008) as follows:

0 perating $\cos t=a C_{\text {energy }}+b C_{\text {electrode }}$

Where, $\mathrm{C}_{\text {energy }}\left(\mathrm{KWh} / \mathrm{m}^{3}\right)$ and $\mathrm{C}_{\text {electrode }}\left(\mathrm{kg} \mathrm{Al} / \mathrm{m}^{3}\right)$ are the consumption quantities for the TD and BOD removal. While"a" electrical energy price $0.1 \mathrm{US} \$ / \mathrm{kWh}$; "b" electrode material price $3.4 \mathrm{US} \$ / \mathrm{kg}$ for Al electrode. Cost due to electrical energy $\left(\mathrm{KWh} / \mathrm{m}^{3}\right)$ is calculated as:

$$
C_{\text {energy }}=\frac{U \times I \times t_{E C}}{v}
$$

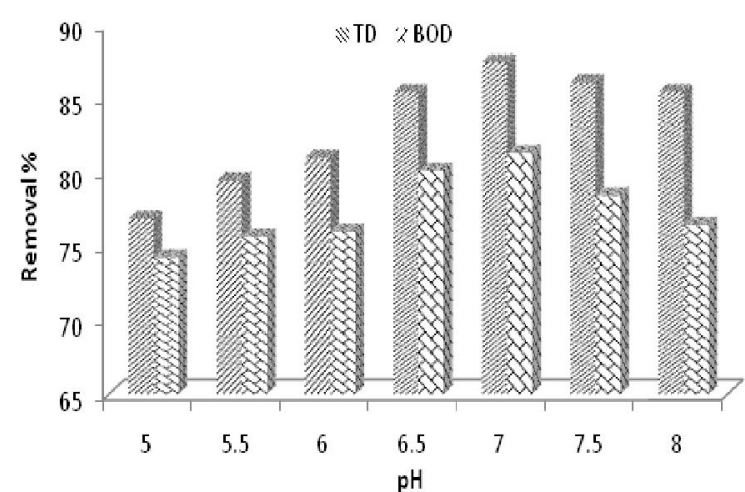

Fig. 4. Effect of $\mathrm{pH}$ on TD and $B O D$ removal efficiency from STS (current density $7.52 \mathrm{~mA} / \mathrm{cm}^{2}$; operating time $40 \mathrm{mins}$.).

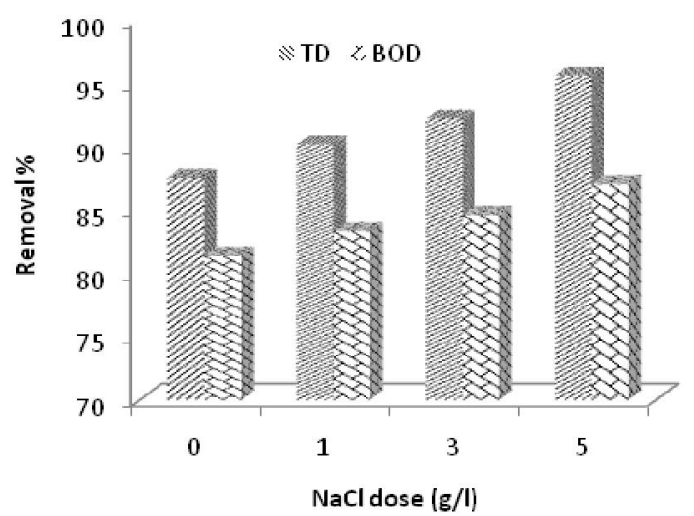

Fig.5. Effect of supporting electrolyte $(\mathrm{NaCl}) \mathrm{g} / \mathrm{l}$ on TD and B OD removal efficiency of STS (current density $7.52 \mathrm{~mA} / \mathrm{cm} 2$; $\mathrm{pH}$ 7). 


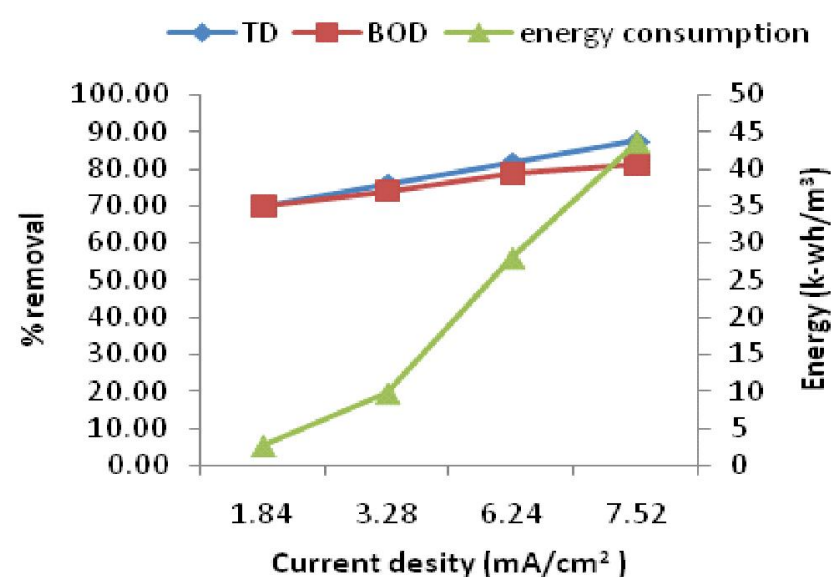

Fig.6. Effect of current density on energy consumption (k-wh/ $\mathrm{m}^{3}$ ) and TD and BOD removal efficiency from STS.

Cost for electrode $\left(\mathrm{Kg} \mathrm{Al} / \mathrm{m}^{3}\right)$ was calculated as follows using the equation:

$$
C_{\text {electrode }}=\frac{I \times t \times M \text { w }}{Z \times F \times V}
$$

Where, $\mathrm{U}$ - cell voltage $(\mathrm{V})$, I- current $(\mathrm{A}), \mathrm{t}_{\mathrm{EC}}$ - time of electrolysis (s) and v- volume $\left(\mathrm{m}^{3}\right)$ of STS water, MW molecular mass of aluminum $(26.98 \mathrm{~g} / \mathrm{mol}), \mathrm{z}$ - no. of electrons transferred $(\mathrm{z}=3)$ and F-Faraday's constant ( $96487 \mathrm{C} / \mathrm{mol})$.

It is evident from Figs. 6 and 7 that the removal efficiency increased from $70.02 \%$ to $87.41 \%$ for TD, $69.8 \%$ to $81.38 \%$ for BOD and the energy consumption increased from $2.76 \mathrm{kwh} / \mathrm{m}^{3}$ to $45.12 \mathrm{kWh} / \mathrm{m}^{3}$ with respect to an increase in current density from 1.82 to $7.52 \mathrm{~mA} / \mathrm{cm}^{2}$ that resulted an increase in the electrode consumption from $2.52 \times 10^{-2}$ to $10.51 \times 10^{-2} \mathrm{~kg} / \mathrm{m}^{3}$. The operating cost of electrolytic treatment was increased from $0.36 \mathrm{US} \$ / \mathrm{m}^{3}$ to $4.87 \mathrm{US} \$ / \mathrm{m}^{3}$ due to increase in electrical energy as well as an electrode consumption in the electrolytic treatment. $K$ inetic Evaluation: The rate of removal of TD and BOD is represented by the following first-order mechanism (Ashtoukhy and Amin 2010):

$$
\ln \left(\frac{\mathrm{C}_{0}}{\mathrm{C}_{\mathrm{t}}}\right)=\mathrm{kt}
$$

Where $\mathrm{C}_{0}$ - initial concentration $(\mathrm{mg} / \mathrm{L}), \mathrm{C}_{\mathrm{t}}$ - final concentration with respect to time, and t- the time (min) and $\mathrm{k}$ - the rate constant $\left(\mathrm{min}^{-1}\right)$ for TD and BOD for electrolytic treatment with varying current density. In the present study, it was revealed that there is a positive correlation between current density and TD and BOD abatement rates and rate of coefficients (Table 2).

The pseudo-first-order abatement kinetic was relatively fitted. The increase in the current density from1.82 to 7.52 $\mathrm{mA} / \mathrm{cm}^{2}$ increased the rate constant from 0.0174 to 0.03 $\mathrm{min}^{-1}$ for TD and 0.0169 to $0.024 \mathrm{~min}^{-1}$ for BOD using $\mathrm{Al}$ electrode. The increase in the rate constant of the kinetic

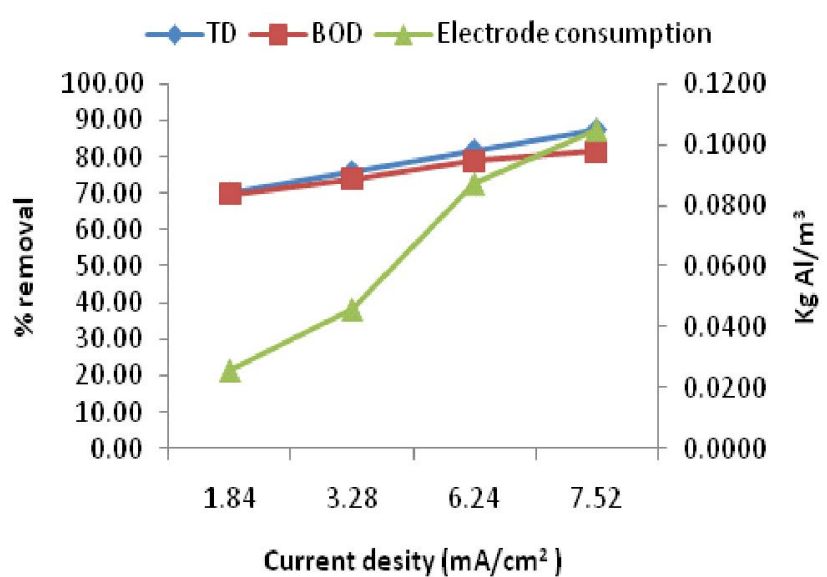

Fig.7. E ffect of current density on electrode consumption (kgAl/ $\left.\mathrm{m}^{3}\right)$ and TD and BOD removal efficiency from STS.

study may be ascribed to the decrease in the concentration of TD and BOD of the STS. The use of this kinetic study showed high correlation coefficients $\left(r^{2}=>0.884\right)$. Thus, the kinetic study is more suitable for explaining the efficiency of current density for electrolytic treatment.

\section{Conclusion}

The removal efficiency of TD and BOD of STS for Al electrodes was found to be dependent on current density, operating time and initial $\mathrm{pH}$ throughout electrolytic treatment. The optimal operating conditions of initial $\mathrm{pH}$ of 7, current density of $7.52 \mathrm{~mA} / \mathrm{cm}^{2}$, and operating time of 40 min increased the removal of TD $(87.41 \%)$ and BOD $(81.38 \%)$ from the STS in the electrolytic cell. Further addition of supporting electrolyte $(0.5 \mathrm{~g} / \mathrm{l} \mathrm{NaCl})$ increased the TD $(95.56 \%)$ and BOD $(86.99 \%)$ at the optimum condition. The energy and electrode consumptions in EC process were increased as current density was increased. The kinetic rate constants for TD and BOD removal at various current densities indicated that pseudo first-order kinetic is in good agreement with the experimental results.

\section{REFERENCES}

Alinsafi, A., Khemis, M., Pons, M.N., Leclerc, J.P., Yaacoubi,

A. Benhammou, A. and Nejmeddine, A. (2005).

Electrocoagulation of reactive textile dyes and textile wastewater, Chem. Eng. Process., 44: 461-470.

APHA (2005). Standard methods for the examination of water and wastewater (21 st Edn). Washington, D.C.: American Public Health Association.

Ashtoukhy, El., and Amin, N.K. (2010) Removal of acid green dye 50 from wastewater by anodic oxidation and electrocoagulation - A comparative study. J ournal of Hazardous M aterials, 179: 113-119.

Bayramoglu, M., Kobya, M., Can, O.T. and Sozbir, M., (2004) Operating cost analysis of electrocoagulation of textile dye wastewater. Sep. Purif. Technol., 37: 117-125.

Bensadok, K., Benammar, S., Lapicque, F., and Nezzal, G. 
(2008). Electrocoagulation of cutting oil emulsions using aluminum plate electrodes. J . H azard. M ater ., 152 (1): 423430.

Bukhari, A. A. (2008). Investigation of the electro-coagulation treatment process for the removal of total suspended solids and turbidity from municipal wastewater. Bioresource Technology, 99: 914-21.

Chen, G. (2004). Electrochemical technologies in wastewater treatment. Separation Purification Technol ogy, 38 : 11-41.

Cho, J.H., Lee, J.E. and Ra, C.S. (2010) Effects of electric voltage and sodium chloride level on electrolysis of swine Wastewater. Journal of Hazardous Materials, 180: 535541.

Chopra, A. K., Sharma, A. K. and Kumar, V. (2011). Overview of electrolytic treatment: An alternative technology for purification of wastewater. Archives of Applied Science Research, 3(5): 191- 206.

Daneshvar, N., Oladegaragoze, A. and Djafarzadeh, N. (2006) Decolorization of basic dye solutions by electrocoagulation: an investigation of the effect of operational parameters. J . Hazard. M ater., 129: 116-122.

Eriksson, E., Auûarth. K., Henze. M. and Ledin. A. (2002) Characteristics of grey wastewater. U rban Water, 4: 85-104

Feng, C., Sugiura, N., Shimada, S. and Maekawa, T. (2003) Development of a high performance electrochemical wastewater treatment system. J. H azard. M ater., 103(1-2): 65-78.

Ghosh D., Medhi C.R., Solanki, H. and Purkait, M.K. (2008) Decolorization of crystal violet solution by electrocoagulation. Journal of Environmental Protection Science, $2: 25-35$.

Gijzen, H.(2002). Anaerobic digestion for sustainable development: a natural approach. Water Science and Technology, 45: 321-28.

Kobya, M., Demirbas, E., Can, O.T. and Bayramoglu, M. (2006). Treatment of levafix orange textile dye solution by electrocoagulation. J. H azard. M ater. 132: 183-188.

Lee, W.J. and Pyun, S.I. (1999). Effects of hydroxide ion addition on anodic dissolution of pure aluminum in chloride ion-containing solution. E lectrochim. Acta. 44: 4041-4049.

Lung Chou, Wei (2010). Removal and adsorption characteristics of polyvinyl alcohol from aqueous solutions using electrocoagulation. J ournal of Hazardous Materials, 177: 842-850.

Mollah, M.Y.A., Schennach, R., Parga, J.R., Cocke, D.L., (2001) Electrocoagulation (EC)- Science and applications. J . H azard. Mater., B 84: 29-41.

Nasrullah, M., Singh, L. and Wahid, Z. A. (2012) Treatment of Sewage by Electrocoagulation and the Effect of High Current Density. Energy and Environmental Engineering J ournal, 1(1): 27-31.

Jolivet, J.P., Solution, D., loxyde. (1994) Condensation des cations en solution aqueuse, chimie des surfaces des oxydes, Inter' Edition, Paris, France, (in French).

Philippe R., Haenni, W. and Pupunat, L. (2003) Water treatment without chemistry. Chimia, 57(10):655-78.

Rahmani, A.R. (2008) Removal of water turbidity by the electrocoagulation method. J . Res. H ealth Sci., 8(1) : 18-24

Szpyrkowicz, L. (2002) Electrocoagulation oftextile wastewater bearing dispersedyes. J. of Ann Chim., 92(10):1025-34.

Tezcan, U., Ugur, U., Koparal S., Bakýr A.S. and Ogutveren, U.(2006). Electrocoagulation of olive mill wastewaters. Separ. Purif. Technol., 52 (1):136-141.

Vlyssides, A.G. and Israilides, C.J. (1997). Detoxification of tannery waste liquors with an electrolysis system. Environ. Pollut. 97: 147-152.

Yetilmezsoy, K., Ilhan, F., Zengin, Z. S., Sakar, S. and Gonullu, M. T. (2009). Decolorization and COD reduction of UASB pretreated poultry manure wastewater by electrocoagulation process: A post-treatment study. J ournal of $\mathrm{H}$ azardous Materials, 162: 120-132. 